\title{
Laser scanning confocal microscopy as a powerful tool for fracture surface characterization.
}

Bábková Petra, CPIT, VŠB-TU Ostrava, 17. listopadu 15, 78033 Ostrava-Poruba. petra.babkova@vsb.cz

Matějka Vlastimil, CNT, VŠB-TU Ostrava, 17. listopadu 15, 78033 Ostrava-Poruba. E-mail: vlastimil.matejka@vsb.cz

The aim of this paper is to show the applicability of the Laser Scanning Confocal Microscopy (LSCM) for the fractographical research of the compact tension specimens. Scanning Electron Microscopy (SEM) together with Light microscopy (LM) are prevailing techniques for the fracture surfaces examination [1,2]. Information about the surface topography obtained by LM and SEM is reflected in 2D image whereas LSCM provides 3D images. In this work the fracture surfaces of the compact tension specimen were examined by LSCM and by SEM and the main features as cleavage facets, ductile dimples, stretch zone and fatigue were observed.

Keywords: LSCM, SEM, fractography, 3D image

\section{References}

[1] ASM Handbook, Vol. 11, 10th Ed., Failure Analysis and Prevention, ASM. 2002. ISBN: 0-87170-704-7

[2] ASM Handbook, Vol. 9, 8th Ed., Fractography and Atlas of Fractographs, ASM. 1992. ISBN 0-87170-007-7 (v. 1).

[3] CWAJNA, J., ROSKOSZ, S. Application of confocal laser scanning microscopy, atomic force microscopy, and the profilometric method in quantitative fractography. Materials, vol. 46. 2001. pp. 183-187.

[4] HANLON, D.N., et al. The application of laser scanning confocal microscopy to tribological research. Wear, Vol. 251. 2001. pp. 1159-1168.

[5] ONDRA, JOSEF. Fraktálni analýza přesných povrchi̊. Strojírenská technologie VI, prosinec. 2001, s. 20-26. 12114162

[6] VACKÁR, JOSEF, PERNÍKÁR, JIRÍ. Methods of Objective Assessment of the Representative Value of Surface Structure Parameters. Manufacturing Technology III, June. 2002. pp.16-20. 12132489

[7] HEIN, L.R.O. Quantitative fractography by digital image processing: NIH Image macro tools for stereo pair analysis and 3-D reconstruction. Journal of microscopy, Vol. 204. 2001. pp. 17-28.

[8] AZEVEDO, C.R.F, Marques, E.R., Three-dimensional analysis of fracture, corrosion and wear surface. Engineering Failure Analysis 17. 2010. pp. 286-300.

Reviewers:

Prof. Ivan Lukáč, MSc., PhD. Assoc. Prof. Dalibor Vojtěch, Ph.D. 